\title{
International volunteer tourism and youth travelers - an emerging tourism trend
}

\begin{abstract}
This study attempted to examine the intricate associations among volunteer tourism (VT) motivations, overall image, satisfaction, trust, and the influence of these relationships on behavioral intentions among youth travelers. Our findings from the structural analysis indicated that VT motivations significantly contributed to building positive images, inducing satisfactory VT experiences, and building trust with a VT organization. Our results also demonstrated the competence of the higher-order structure of VT motivations in explicating the intention formation. In addition, the overall image, satisfaction, and trust played an important mediating role. Moreover, satisfaction with VT experiences was of utmost significance in determining intentions.
\end{abstract}

Keyword: International volunteer tourism; Youth travelers; Tourism trend; Overall image; Satisfaction; Trust; Behavioral intentions 